\title{
Report to the Congress on Alternative Financing Methods for the Strategic Petroleum Reserve
}

\section{Executive Summary}

Submitted in Response to the Strategic Petroleum Reserve Amendments Act of 1989 (Public Law No. 101-42).

February 1, 1990

Department of Energy 


\section{DISCLAIMER}

This report was prepared as an account of work sponsored by an agency of the United States Government. Neither the United States Government nor any agency Thereof, nor any of their employees, makes any warranty, express or implied, or assumes any legal liability or responsibility for the accuracy, completeness, or usefulness of any information, apparatus, product, or process disclosed, or represents that its use would not infringe privately owned rights. Reference herein to any specific commercial product, process, or service by trade name, trademark, manufacturer, or otherwise does not necessarily constitute or imply its endorsement, recommendation, or favoring by the United States Government or any agency thereof. The views and opinions of authors expressed herein do not necessarily state or reflect those of the United States Government or any agency thereof. 


\section{DISCLAIMER}

Portions of this document may be illegible in electronic image products. Images are produced from the best available original document. 


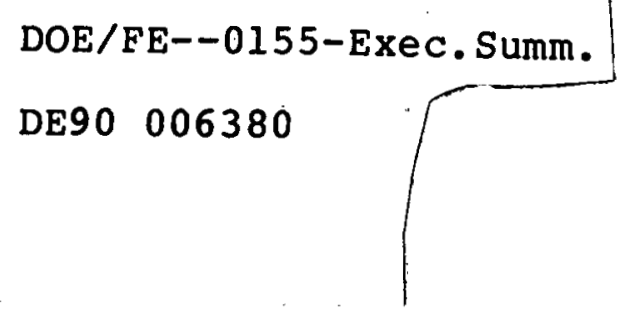

Report to the Congress on

Alternative Financing Methods for the Strategic Petroleum Reserve

\section{Executive Summary}

Submitted in Response to the Strategic Petroleum Reserve Amendments Act of 1989 (Public Law No. 101-42).

February 1, 1990

Department of Energy

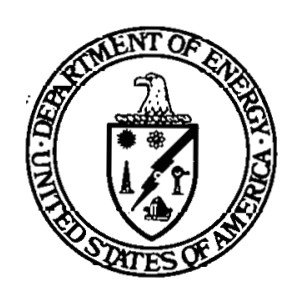




\section{EXECUTIVE SUMMARY}

\section{A. INTRODUCTION}

\section{Background}

The Strategic Petroleum Reserve (SPR) was authorized in 1975 by the Energy Policy and Conservation Act (EPCA) to reduce the vulnerability of the United States to interruptions in oil supplies. Under plans developed in the 1970's, the SPR is a Government-owned crude oil inventory stored in salt caverns in Texas and Louisiana. Through Fiscal Year 1989, over 577 million barrels (MMB) of crude oil were stored in the SPR, and facilities are being developed to store a total of $750 \mathrm{MMB}$.

Under current practice, the Federal Government owns the SPR crude oil and the storage facilities. The funds to acquire and maintain the Reserve generally have been derived from normal Federal budget resources; $\$ 20$ billion in appropriated funds have thus far been made available.

The use of the SPR is governed by the EPCA, which provides the President with broad discretion on when and how the SPR inventory is to be used. Present plans for SPR use call for price-competitive sale as the primary means of distributing the oil into the economy. By owning and selling SPR oil, the Government acts directly as an economic agent in response to an energy supply interruption.

During 1989, in Public Law No. 101-46, the Congress extended the EPCA authorities until April 1, 1990 and required the Department of Energy (DOE) to conduct a study of alternative ways of financing the Reserve, with a final report on the study to be submitted by February 1, 1990. The Administration decided to undertake the study of alternative SPR financing methods in conjunction with a parallel study of SPR size, through an Interagency Steering Group, chaired by the DOE Deputy Under Secretary. Day-to-day responsibility for the study was assigned to an Interagency Working Group comprised of representatives of interested Federal agencies.

\section{Study Activities}

The Working Group activities were carried out in compliance with the requirements of Public Law No. 101-46, as follows:

- $\quad$ Requirement: Assume a decision to fill the SPR to one billion barrels at a rate of at least 75 thousand barrels per day (75 MBD). 
Activity: This study analyzed three SPR sizes (750 MMB, 850 $\mathrm{MMB}$, and 1,000 $\mathrm{MMB}$ ) and three fill rates (50 MBD, 75 $\mathrm{MBD}$, and $100 \mathrm{MBD}$ ), thus meeting the requirement. The SPR size study was focused on the economic benefits and costs of various SPR size levels.

- $\quad$ Requirement: Consider a broad array of alternative methods for financing the SPR.

Activities: The study addresses the following alternatives:

- $\quad$ "leasing" oil for the SPR, including lease/option and lease/purchase methods;

- $\quad$ selling oil-denominated bonds;

- using the Naval Petroleum Reserves to fill the SPR;

- imposing petroleum fees, with new revenues earmarked for the SPR expansion;

- mandating private sector nil storage; and

- leasing storage facilities for the SPR on a long-term or short-term hissis.

Some of these alternatives involve policies that the Administration has opposed in other forums. In particular, the Bush Administration continues to strongly oppose any increase in petroleum fees, charges, or taxes. The discussion of these alternatives here does not reflect a change in such Administration positions. Rather, they have been included solely to address the Congress' request for consideration of a broad range of policy alternatives. These alternatives have been rejected by the Administration for policy reasons.

The Department of Energy published a Notice of Inquiry in the Federal Register inviting ideas from the public on innovative financing methods, and ideas received in response to this notice are addressed in the study.

- Requirement: Consult with persons in the private sector who might be interested in leasing.

Activities: Consultations were undertaken with private firms that might be interested in leasing facilities to the Government for the SPR. In addition, the Working Group held a discussion 
of innovative financing methods with a panel of members of the financial community.

- $\quad$ Requirement: Initiate discussions with foreign governments on oil leasing or other concepts.

Activities: Working Group members from the Departments of Energy and State held exploratory discussions with representatives of the governments and/or state-owned oil companies of Kuwait, Mexico, Norway, Saudi Arabia, and the United Arab Emirates. Other, less detailed discussions were held by the DOE with representatives of Nigeria, Venezuela, and the United Kingdom. In addition, the Department of Energy corresponded with members of the Governing Board of the International Energy Agency (IEA) and received comments from several members.

- $\quad$ Requirement: Produce preliminary written solicitations for oil and facilities leasing.

Activities: Preliminary drafts of such solicitation materials have been prepared, and are being forwarded to the Congress as Volume II of the study.

- Requirement: Transmit an Interim Report to Congress by October 15, 1989.

Activities: The Department of Energy transmitted the Interim Report to Congressional committees on October 13, 1989.

- $\quad$ Requirement: 'Transmit a report to the Congress by February 1,1990 on the findings and conclusions of the study, along with legislative changes that would be necessary to authorize the most significant options (specifically including leasing of oil and facilities).

Activitics: The principal findings and conclusions of the study are summarized in this document; Volume I of the report contains drafts of the legislative changes that would be required to authorize oil and facilities leasing.

Any recommendations of the Secretary will be transmitted to the Congress, separate from this summary and the report it summarizes. 


\section{Analytic Approach}

A first step in the study process was to establish reasonable analytic parameters. The following boundary conditions were set for inclusion of alternatives in the study process:

- $\quad$ The study would focus on continued storage of crude oil in the SPR and would not reexamine the issues associated with refined product storage that were addressed in the April 1989 DOE report to Congress, Report to the Congress on Expansion of the Strategic Petroleum Reserve to One Billion Barrels.

- It was assumed that solution-mined salt caverns. would be the preferred storage medium for permanent SPR storage, also as recommended in the April 1989 report.

- Completion of the current plans for $750 \mathrm{MMB}$ in storage capacity at the six existing SPR sites was assumed, such that alternative facilities financing concepts would apply only to further expansion of the Reserve.

- $\quad$ The current SPR crude oil specifications were assumed to be retained for the first $750 \mathrm{MM} \overline{\mathrm{B}}$ of the SPR.

- It was assumed that alternative oil financing methods would apply only to future fill of the Reserve, and that the first 600 MMB would not be subject to refinancing.

The study did not consider the sale of Federal assets unrelated to the SPR on the grounds that, with the exception of the Naval Petroleum Reserves, decisions to sell Federal assets would be made independent of decisions concerning the SPR. The study also did not consider simple changes in budget scorckeeping methods, such as "off-budget" treatment of SPR spending, because such changes would not affect underlying sources of tinancing. Finally, the study did not consider proposals concerning the use of commercial futures or options in SPR inventory management activities on the grounds that the techniques proposed would address only a small proportion of SPR capital costs. 


\section{Evaluation Criteria}

Emphasis was placed on five evaluation criteria derived from section 160(b) of the EPCA:

- minimization of cost;

- $\quad$ orderly development of the Naval Petroleum Reserves, where applicable;

- $\quad$ minimization of U.S. vulnerability to suppiy disruptions;

- minimization of market impacts; and

- encouragement of competition.

Other policy evaluation factors were introduced in conjunction with specific alternatives.

\section{Baseline for Analysis}

Financing alternatives were compared to the anticipated costs of continuing the current approaches of buying SPR oil outright and financing the Reserve from general Federal budget resources. Three different SPR sizes were considered, three different fill rates were analyzed, and three different oil price cases were assumed. The price cases were derived from the April 1989 Annual Energy Outlook of the Energy Information Administration, with prices extended beyond the year 2000 through an oil market simulation model. The real dollar price projections were converted to nominal dollars through the use of mid-1989 inflation rate projections extended into future years at an assumed annual inflation rate of 3 percent.

Table I provides a summary of price levels for selected fiscal years.

Table I

Average Refiner Acquisition Cost for Imported Oil (Nominal Dollars per Barrel)

\begin{tabular}{|c|c|c|c|}
\hline Fiscal Year & Low Case & Base Case & High Case \\
\hline 1990 & $\$ 13.83$ & $\$ 16.07$ & $\$ 19.24$ \\
\hline 1995 & 19.98 & 24.47 & 29.11 \\
\hline 2000 & 30.06 & 39.06 & 48.48 \\
\hline 2005 & 40.18 & 54.04 & 67.70 \\
\hline
\end{tabular}

A Reference Case was established, combining the Base Case price projections with an assumed fill rate of $75 \mathrm{MBD}$, and assuming continuation of the current approaches of buying SPR oil outright and finaricing the Reserve through the general Federal budgct. 
Table II provides a financial summary of the Reference Case (in nominal dollars except when noted). Key findings include the following:

- Completion of a $750 \mathrm{MMB}$ system at $75 \mathrm{MBD}$ (by Fiscal Year 1996) would involve annual budget outlays of approximately $\$ .8$ billion through FY 1996 and $\$ .2$ billion thereafter, for a total cost of $\$ 6.3$ billion through FY 2005. The present value of such costs would amount to nearly $\$ 4$ billion using the 10 percent real discount rate prescribed by OMB Circular A-94, and the total investment, including Treasury borrowing costs, would amount to nearly $\$ 14$ billion by 2005 . Thus, if it is assumed that borrowed funds would be used to complete the Reserve, more than half of the total Federal budget costs through 2005 would be borne by Treasury appropriations for interest on the Federal debt.

Table II

Financial Summary

Reference Case

(billions of dollars, FY 1991-2005)

Financial Measures

Total Budget

Outlays

Avg. Annual

Outlays

FY 1991-1996

FY 1997-2000

FY 2001-2005

Presont Valuc

Costs (\$1991)

Tntal Treasury

Cost

(Interest)

Market Value in FY 2005

Completion Year

$\frac{3 \text { Size Increments_(MMB) }}{600-750 \quad 750-850}$

$\$ 6.3$

$\$ 3.9$

$\$ 8.5$

$\$ 18.8$
Thtal

$\underline{600-1,000^{2 !}}$

$\$ 0.8$

0.2

0.2

$\$ 3.9$

$\$ 1.8$

$\$ 2.5$

$\$ 0.2$

0.2

1.3

0.0

$\$ 8.2$

$\$ 13.7$

(7.4)

$\$ 7.2$

(3.2)

$\$ 11.8$

(3.2)

$\$ 32.6$

$\$ 8.1$

$\$ 5.4$

$\$ 8.1$

$\$ 21.6$
$\$ 1.0$

1.2

1.5

2

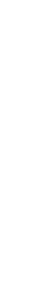

(1)


- A $100 \mathrm{MMB}$ expansion of the Reserve (achieving $850 \mathrm{MMB}$ by 2000 ) could add an additional $\$ 3.9$ billion to the DOE budget through FY 2005, with most costs being incurred in the FY 1997-2000 period, during oil acquisition.

- A further 150 MMB expansion to achieve a one billion barrel SPR by the year 2005 would increase DOE budget requirements by an additional $\$ 8.5$ billion, of which $\$ 7.3$ billion would be for oil. These oil costs would be incurred predominantly after the year 2000 .

- $\quad$ Overall, approximately $\$ 18.8$ billion in direct DOE funding, an average of over $\$ 1$ billion per year would be required to expand the Reserve from the current inventory level to one billion barrels. In present value terms, this total investment is estimated at $\$ 8.2$ billion.

These estimates are sensitive to oil price assumptions and to fill rate decisions:

- Under Low Case oil prices, total DOE costs to reach one billion barrels at $75 \mathrm{MBD}$ would be reduced by $\$ 3$. billion, whereas under High Case oil prices, direct costs would increase by $\$ 3.1$ billion.

- A fill rate of $50 \mathrm{MBD}$ would involve completion of one billion barrels by FY 2013, with 750 MMB attained by FY1999. Costs through completion, in nominal dollars, would increase for the DOE budget ( $\$ 6.7$ billion) and interest expenditures $(+\$ 22.4$ billion), because of the expectation of increasing oil prices and because the additional time to complete would add to standby operating costs and the compounding period of Treasury interest. However, at a 10 percent real discount rate, the present value of this investment would be about $\$ .7$ billion lower than for the $75 \mathrm{MBD}$ fill rate.

- With a $100 \mathrm{MBD}$ fill rate, an inventory of one billion barrels would be completed by FY 2002. Future DOE budget costs would be reduced by $\$ 2.5$ billion, and Treasury borrowing costs would be lower by $\$ 4.8$ billion. In present value terms, the investment cost would be $\$ 8.5$ billion, an increase of $\$ .3$ billion from the Reference Case. 
Several conclusions can be drawn from this analysis:

- There are a number of measures of SPR cost, each of which has meaning for different forms of financial analysis. However, under all measures, future financing requirements for the SPR -- under either the current approach or the alternatives discussed below -. could be very large.

- Over time, Treasury borrowing costs might have a more significant budget effect than the direct DOE capital and operating costs. Therefore, the effects of financing alternatives on the budgets of both Treasury and DOE would need to be considered.

- Much of the cost, except for facilities, of expanding the Reserve beyond $750 \mathrm{MMB}$ would be incurred in the last half of the 1990's or the early years of the next century. Oil market conditions for that period are highly uncertain at this point.

Each of the financing alternatives considered is discussed in the following sections. 


\section{B. OIL LEASING}

\section{Leasing Description}

The Congress directed that the "leasing" of oil by the Government be considered in the analysis of financing alternatives. "Leasing", as used here, encompasses a wide range of transactions involving access to and storage of oil not owned by the U.S. Government, but subject to its control.

SPR oil leases could take a variety of forms. One approach, the primary case for analysis and for drafting the preliminary written solicitation contained in Volume II, is what has been termed the "lease/option" method. A second approach, termed the "lease/purchase" method, under which the Government would buy the oil during the lease period, is also discussed in Chapter VI of Volume I.

Under the lease/option method, the SPR would receive "wet" barrels of oil from an investor (the lessor) who would contract to leave oil in SPR storage for a defined period of time (lease term) in return for periodic payments. During the lease term, DOE would control the oil and could make any of the following decisions:

At the end of the term:

- Acquire the oil at a predetermined price; or

- Return the oil to the lessor; or

- $\quad$ Renew the lease under procedures set forth in the contract.

In the event of a disruption before maturity:

- Cause the oil to be sold, with some or all of the proceeds paid to the lessor; or

- Acquire the oil at a predetermined price; or

- Do nothing; permit the lease to run to maturity.

In this primary case, the U.S. Government reserves all of these options for itself. Variations could include the following:

- Reservation of some of these options to the lessor;

- Requiiring mutual agreement before the exercise of certain options, such as extension options; and 
- $\quad$ Setting conditions for the exercise of some options, such as precluding return of wet barrels to the lessor if market prices had not reached certain minimum levels.

The reasons for vesting the options in the Federal Government in this primary "lease/option" case were (a) to retain the strategic character of the Reserve and (b) to reduce the need for significant additional budget authority. The study recognizes that, at the time of the lease agreement, the Department would need sufficient budget authority to cover all lease payments for the minimum term of the lease and to cover any potential obligations incurred by vesting decision-making in the lessor rather than the Government.

While the structure of decision-making is possibly the most important design feature of a lease, there are numerous other lease design features that need to be addressed. For purposes of preparing draft lease solicitation materials, a 10-year initial term was assumed, reflecting a trade-off between the desirability of reducing budget authority requirements through shorter terms, and the attractiveness of longer terms for strategic and managerial reasons. The minimum size for a competitively procured oil lease was set at 5 million barrels, to be delivered over the course of a year. Smaller lease sizes might attract more competition, but would also greatly increase the number of lessors with whom the Department would need to deal.

Some lease contractual provisions would be similar to those of SPR crude oil purchase contracts. However, a lease, unlike a purchase, would establish a continuing relationship between the two parties, for periods of a decade or longer; special provisions would be required to clarify each party's rights and responsibilities over this period.

Two different approaches could be taken to contracting for SPR oil leases. First, the Department could issue a competitive solicitation with standardized terms and conditions and request private offers that would be evaluated largely on the basis of the annual fee payments bid. This is the concept which has been employed in drafting the preliminary solicitation contained in Volume II.

Federal procurement laws and policies favor the use of a competitive approach where possible. Contacts with representatives of industry suggested that there could be interest in using oil leases as financial instruments. However, the Working Group also identified significant barriers to meeting SPR oil acquisition requirements by competitive oil leasing:

- Owners of oil assets have faced considerably more financial risk in recent decades than have owners of debt securities or corporate stock. In general, investments with higher risk require higher rates of return. The oil leasing method involves the Government's sharing the ownership risk of oil with the lessor, and it is doubtful that such arrangements could be 
undertaken with the private sector unless the Government paid an effective rate of return in excess of Treasury borrowing rates.

- There is strong evidence that the oil price projections being used in private investment are below those of the Base Case used in this study. This is important insofar as the expected appreciation in the value of the asset is counted upon to offset a portion of the financing cost. This differential in expectations would make it less likely that the Government could achieve a financial arrangement which it would consider attractive.

- $\quad$ SPR oil leasing would be a new approach for the Government and the business community. Some complex contract terms might be more appropriately handled through bilateral negotiations rather than through price-competitive bidding.

- While there is a growing market for oil-backed financial securities, including futures, options and "swaps", the very minimum size SPR lease ( 5 million barrels, or roughly $\$ 100$ million) and the lease duration (10-year maturity) would be large in relation to other financial instruments now being traded. Decreasing minimum sizes or shortening terms to attract more participants would, however, greatly complicate the SPR management process, by expanding the number of continuing relationships to be administered.

Second, a contrasting approach to oil leasing would be for the United States to negotiate one or more lease agreements on a bilateral, country-to-country basis, with the agreement tailored to meet the needs of a particular lessor. This approach might be especially relevant in the case of a major crude oil producing nation. One reason might be that the foreign producer could produce additional quantities of oil for leasing purposes, converting assets that would otherwise not be monetized for decades into current financial assets.

Public Law No. 101-46 called for the Departments of Energy and State to discuss oil leasing or other financing methods with representatives of such countries. During the study preparation period, exploratory discussions were held with Kuwait, Mexico, Norway, Saudi Arabia, and the United Arab Emirates. Less detailed discussions were held with Nigeria, the United Kingdom and Venezuela.

The economic circumstances of the countries with which detailed discussions were held varied widely. Some rely on cash sales of crude oil to meet their national budget and foreign currency requirements. Oil leases, on terms attractive to the U.S., would be less 
likely to emerge from discussions with countries without excess production capacity than from negotiations with countries that have excess production capacity and less compelling oil sales income requirements.

The following are some of the principal points made in these consultations:

- In all cases, participants recognized that the discussions were exploratory in nature. The United States representatives were not presented with firm offers, nor were any firm U.S. proposals made.

- The role of the SPR in U.S. energy policy was understood and the potential for cooperating with the U.S. in filling the SPR was in no instance rejected. Indeed, there were indications that this type of cooperation could be viewed as a positive feature of oil leasing.

- Some countries indicated an interest in seriously exploring the possibility of an SPR oil "lease" or comparable arrangement.

- For countries that appear more willing and able to undertake oil leasing, several important concerns were raised:

-- Competitive Bidding: Producer governments expressed unwillingness to bid for an oil lease in an open competition; some countries however, indicated an interest in having further bilateral discussions to pursue mutually beneficial lease terms.

- Taxes: The potential applicability of Federal, state, and local taxes either to periodic fees or to sales gains on assets was viewed as a major obstacle, which would need to be addressed either through higher contract payments or special tax treatment. Under the current SPR cash purchase approach, foreign sellers are liable for no U.S. taxes.

- Cargo Preference: Some governments had a strong preference for arranging their own shipping of crude oil for the SPR, rather than having 50 percent of the oil transported in U.S.-flag ships. Even for others, it is clear that 
the U.S. Government would have to absorb the extra costs associated with use of U.S.flag vessels.

-- Return of Capital: Some nations expressed concern about the potential for having the oil returned to them at the option of the U.S., potentially under unfavorable market conditions. Some also expressed concern over the potential for having their oil sold under non-emergency conditions.

-- Commercial Uses: Some nations are interested in storing oil in or near the U.S. market for commercial reasons, which could involve either collocating commercial stocks in facilities storing SPR oil or providing limited producer nation access to its leased oil.

Based on these discussions, there appears to be a clear potential for negotiating oil "leases" with one or more foreign producing nations, but the more feasible approach would involve bilateral negotiations on a country-to-country basis. One possible reason for conducting multiple bilateral discussions would be to accommodate SPR plans for storing multiple types of crude oil.

\section{Lease Evaluation}

Because the Federal Government has not received specific oil leasing proposals, no definitive judgments could be made on the cost of SPR oil leasing relative to outright purchases. The primary approach taken to the financial evaluation of the leasing concept was "breakeven" analysis to determine the range of conditions under which the costs of hypothetical lease proposals might be equal to or less than the costs of continued direct purchases. This approach was implemented by comparing the cost of leasing to the cost of continued cash purchases as called for by Office of Management and Budget (OMB) Circular A-104, coupled with sensitivity analysis concerning oil prices, discount rates, and contract structure. This approach yielded a broad range of lease payment levels, each of which would be considered "breakeven" from a Federal Government perspective under specific circumstances, i.e., the Government would be unwilling to lease at costs in excess of the costs of direct purchase.

The A-104 methodology involves the use of present value analysis, wherein the present value of the "purchase" cost is the net of the initial purchase price, less the present value 
of the asset resale value at the end of the period under analysis. The "lease cost" is the present value of the lease payments. The discount rate used for A-104 is the Treasury borrowing rate for comparable maturities, plus one eighth of a percent.

The conclusions of this "breakeven" analysis can be summarized as follows:

- Under the assumptions used in the study, the price of oil is projected to rise by approximately the same rate as the interest rate, for more than a decade. The Government's breakeven lease payments for ten-year leases awarded in the next several years could even be slightly negative, theoretically calling for a storage payiment from the lcssor, if the lessor would receive all appreciation in the value of the oil.

- With longer maturities than ten ycars, or for ten-yeur leases awarded in future years, the breakeven annual lease payment levels would be higher due to a combination of higher initial oil prices and lower appreciation rates.

- A one percent increase in the discount rate represents approximately a $\$ .20$ to $\$ .25$ per barrel increase in the annual lease payment, for ten year leases awarded in the early 1990's.

- Lessors with lower oil price growth expectations than those of the Federal Government would only be able to offer breakeven lease arrangements if they had lower oil costs or access to mnitnl hasring lower interest rates.

- In determining the price at which the Government would have the option to buy the oil, the lease contract could establish a cap, or upper bound, on such option price. With a cap on price appreciation equal to a 5 percent annual increase from the original market value, the breakeven lease payment for a lease in the early years would amount to approximately $\$ .60$ to $\$ .70$ per barrel per year, rising for leases issued in later years. This was the case used for the analysis below of budget effects.

- For the lease/purchase method, if the price of the oil is amortized over a ten-year period, and the lessor receives no price appreciation, the Federal breakeven annual payment for a ten-year lease starting in FY 1991 would be approximately $\$ 2.56$ per barrel, rising to $\$ 8.05$ per barrel for leases starting in 2005. The differences between these payment levels and 
those of the lease/option method are that the principal value is amortized in the lease/purchase approach and the lessor receives no price appreciation benefits to offset interest costs.

In sum, the study results indicate that leasing of SPR oil through competitive commercial arrangements is unlikely to result in contract terms favorable to the U.S. Government. A favorable lease arrangement is likely to involve a government-to-government agreement with a leading oil producing country. Leasing oil for the SPR would be a viable alternative only to the extent that its costs would be less than the costs of direct purchase. The private sector's cost of capital is higher than Treasury's, but some producing countries have unused production capacity that may permit the lease of oil to the SPR at lower than commercial rates.

\section{Budget Effects}

In general, leasing would have the following budget effects:

- Transfer budget requirements for interest from the Treasury Department to the SPR;

- $\quad$ Reduce near-term budget outlay (BO) requirements;

- In the case of the lease/option method, reduce initial budget authority (BA) requirements because of deferred decisions on making principal payments;

- In the case of the lease/purchase method described above, increase initial BA requirements, to account for both principal and future interest; and

- In buth cases, reduce the ownership of the Federal Government in the oil at the time of a drawdown.

Table III provides a summary comparison of budget effects over the FY 1991- FY 2005 period under each alternative, assuming a $75 \mathrm{MBD}$ fill rate, 8 percent Treasury borrowing. cost, Base Case oil prices, a 5 percent cap on price appreciation for the lease/option method, and ten-year lease periods. 
Table III

Summary Comparison of Budget Effects

(FY 1991-2005, Nominal Doilars in Billions)

Direct

Purchase

\author{
$\$ 8$
4
}

Lease/Option

No Purchase Purchase

$\$ 10$

8
Lease/

$\underline{\text { Purchase }}$

DOE Budget

BA

BO

$\$ 15$

15

$\$ 21$

11

Total Budget

BA

BO

MMB Owned

$\$ 25$
25

$\$ 10$

6

$\$ 13$

10

$\$ 27$

17

411

0

137

260

Contingent

Claim (MMB)

0

411

274

151

The lease/option method with no exercise of purchase options (denoted as No Purchase in Table III) involves the lowest total Federal budget effect, but results in contingent claims rather than ownership of the crude oil. Both the lease/option-with-purchase and the lease/purchase method increase the Federal ownership stake, but require additional $\mathrm{BA}$ and $\mathrm{BO}$. The lease/purchase method actually involves more total BA than outright purchase, because lease payments for the post-2005 period have been obligated by the year 2005, but cash outlays (and equity interest in the inventory) are lower than for outright purchases.

This analysis assumes that the SPR fill rate would be unaffected by the selection of acquisition methods. An alternative analysis was undertaken to estimate the total amount of oil that could be acquired from a fixed amount of DOE budget authority. For this example, a $\$ 3$ billion level of budget authority was used, representing the approximate requirements for BA to achieve $75 \mathrm{MBD}$ over the FY 1991-95 period through outright purchase at Base Case prices. The results of this analysis are presented in Table IV. 


\section{Table IV}

Oil Deliveries from \$3 Billion BA

\section{Method}

Direct Purchase

Lease/Option

Lease/Purchase
(MMB)

137

324

108

This analysis focuses only on the near-term, during which ten-year contracts would not expire; hence, the purchase options of the lease/option concept would not require exercise. It should be noted that the near-term outlays for the lease/option method would be significantly below the outlays under either of the other methods.

In sum, oil leasing could have significant effects on Federal budget levels and/or SPR fill rates, but the effects would be different for BA and cash outlays and would depend on the structure of the lease agreement negotiated. The Government would be obtaining contingent claims rather than outright ownership of the oil in question.

Near-term Federal outlays could be reduced by either of the leasing methods analyzed, but with a fixed level of budget authority assumed, the lease/option method would result in higher SPR oil deliveries. 


\section{C. - OIL-INDEXED BONDS}

\section{Oil Bond Description}

Under this alternative, the Federal Government would market special financial securities denominated in a specific number of barrels. The payment of principal and interest to the investor would be based on the price of oil at maturity. The particular approach used for analysis was "zero-coupon" in the sense that all principal and compound interest would be paid at maturity, assumed to be in ten years. The Government would set a maximum rate of return (13 percent was used for calculation), and the investors would bid a minimum rate of return.

For example, if oil prices were $\$ 17.19$ per barrel in FY 1991, a bond might be issued at that price, with a redemption value in FY 2001 that was the year 2001 price of oil, subject to a maximum payment of $\$ 58.34$, which is the original principal plus a 13 percent compound rate of return over the ten-year period. Investors would be requested to bid a minimum rate of return, expressed as the minimum redemption value at the end of the period. Assuming that the investor wanted a minimum rate of return of 5 percent, it would bid $\$ 28$. If oil prices in 2001 were under $\$ 28$, the investor would still get its $\$ 28$, hence the minimum yield of 5 percent. If oil prices were between $\$ 28$ and $\$ 58.34$, the investor would receive the actual oil price, and if oil prices were over $\$ 58.34$, the investor would receive only this maximum payment.

Alternatively, if an investor demanded a minimum rate of return equal to the assumed Federal borrowing rate of 8 percent, the investor would bid a minimum price of $\$ 37.11$ per barrel. This would entail a minimum cost of Federal financing that was at least as high as current Treasury borrowing, yet it would leave the Government exposed to potentially higher costs, depending on oil price trends.

\section{Financial Effects}

Whether the Government would gain or lose from this approach would depend on two principal factors. First, it would depend on where oil prices actually ended up. Second, it would depend on the minimum yield bid. by investors. Preliminary market research suggests that, under some projections that seem to mirror those of the financial markets, the minimum yields bid would be in the neighborhood of 7.5 percent, reflecting a relatively small discount from the assumed Treasury borrowing rate of 8 percent.

In assessing any form of oil-bond financing, the following critique must be borne in mind: to the extent that capital markets function efficiently, the use of oil-linked bonds cannot hope to achieve a lower expected cost of financing than direct Treasury financing. Indeed, the presumption must be that private investors would require a higher expected rate of return on oil bonds than on Treasury securities, to compensate for the added risk associated with the oil bonds. 
Furthermore, the argument that oil bonds entail a "win-win" proposition when investors are more optimistic about oil prices than the Government must be regarded with a great deal of caution, because only one party will turn out to be correct.

Thus, two issues posed by oil bonds would be:

- Whether the Government should be willing to pay higher expected financing costs when oil price risk is shared with private investors; and

- How the Government should respond to divergences between its own energy market projections and those of potential investors.

In addition, the oil bonds would represent a new type of security, and the market's acceptance of these instruments is uncertain. The Government would likely incur higher debt administration costs (underwriting, etc.) or interest costs.

The budget effects of oil bonds can be summarized as follows:

- $\quad$ Near-term SPR budget authority requirements would increase dramatically; in the example above, the BA requirement in FY 1991 would be $\$ 58.34$ per barrel, or over $\$ 40$ more than outright purchase. This is due, in about equal proportions, to:

-- The transfer of all future Treasury borrowing costs into a current DOE budget estimate; and

-- $\quad$ The need for budget authority to cover the full potential liability of the bond.

- Federal cash payments would be reduced to zero until maturity, both for DOE and the Treasury, because of the zero-coupon feature of the bond. However, the actual budget scorekeeping for outlays would need to be defined if this option were implemented. For example, the Federal budget treats as outlays the accrued interest on Treasury-issued zerocoupon bonds, even though bondholders do not receive a payment until maturity. 


\section{Other Factors}

Oil bonds are similar to certain forms of oil leases in that they rely on the investor's expectation of appreciation of the principal to induce the investor to accept below-market guaranteed yields. Indeed, oil bonds with parallel terms could be issued by an oil lessor to satisfy its financing needs, since a bond liability could be matched to a lease asset. Bonds have the advantage that they can be issued in smaller denominations to a broader range of investors than oil leases. Standardizing bond terms would permit them to be used in conjunction with other oil-backed financial instruments such as futures, options, or commodity "swaps".

Oil bonds could have uinlque tax effecls which would nced to be explored further. One interpretation is that only the minimum rate of return would be considered as current interest income to a taxpayer, while taxation on the remaining return would be deferred until maturity.

Consideration would also need to be given to the manner in which bonds would interact with SPR drawdown procedures. Alternatives considered in the study included:

- $\quad$ Providing the Government with the option to call the bonds at the maximum yield during a disruption;

- Permitting investors to use oil bonds to pay for SPR oil during a drawdown; and

- Requiring underwriting institutions to make a market for oil bonds, to increase liquidity.

Some variations of both oil leasing and oil bonds would entail establishing upper bounds, or "caps", on the Federal Government's liabilities to investors. This might be interpreted as advocacy for inappropriate limits or controls on oil prices.

In sum, oil bonds are financial liabilities that could be matched to asset valucs. The Government would be exposed to explicit financial gains and losses based on actual oil market trends in relation to expectations. 


\section{NAVAL PETROLEUM RESERVES OPTIONS}

The Federal Government owns significant petroleum production assets in the Naval Petroleum Reserves (NPR), most notably at NPR-1, the Elk Hills oil field in California. There have been a number of legislative and policy interrelationships between the SPR and the NPR over the past two decades, and four alternatives have been assessed for using Elk Hills resources as a basis for filling the SPR and for creating a Defense Petroleum Inventory (DPI).

- Direct Delivery

Some Elk Hills crude oil could be transported directly to the SPR. However, delivery rates would initially be less than 50 MBD and would decline from that level. The study concludes that, after transportation costs and other factors are considered, this option would not provide net benefits in comparison to continued direct sales of Elk Hills oil in California and direct purchases of SPR oil.

- Revolving Fund

Under this approach, Elk Hills profits would be used to finance the SPR rather than for direct deposit into the Treasury. While there would be no net effect on the total budget deficit, such a revolving fund could provide added management flexibility, including taking advantage of attractive capital investment opportunities at Elk Hills.

At Base Case prices, depenäing on Elk Hills production forecasts, Elk Hills profits could support an SPR fill rate of approximately 40-50 MBD over the coming decade, adding 162 to $183 \mathrm{MMB}$ to the SPR by the year 2000 . Thus, this option would not finance expansion to $1,000 \mathrm{MMB}$ or the fill rate of $75 \mathrm{MBD}$, and would need to be combined with other options in order to achieve these goals.

- Elk Hills Divestiture

In 1986, the Reagan Administration proposed that the Federal Government's interest in Elk Hills be sold, and this idea has been reflected in budget documents in succeeding years. In 
general terms, an outright sale of these assets would have the following budget effects:

-- A significant near-term cash payment into the Federal Treasury;

-- A reduction in Federal proprietary receipts in future years;

-. . An increase in Federal income tax revenues; and

-- An increase in state and local tax revenues.

In comparison to the revolving fund approach discussed above, one would expect outright sale of Elk Hills to accelerate the availability of funds for SPR oil fill, but to reduce the total amount of SPR oil purchasing capabilities because of the diversion of Elk Hills income to taxes. Also, to the extent that interest on unused balances of the initial cash payments was not credited to the SPR, a portion of the benefits of accelerated cash receipts would accrue to the overall Federal budget but not to the SPR.

The study assumed a broad range of possible sales values for Elk Hills if sold in September 1991, ranging from $\$ 1.6$ to $\$ 3.6$ billion. If actual oil prices tracked closely with purchaser expectations, a range of $84 \mathrm{MMB}$ to $128 \mathrm{MMB}$ of SPR oil could be acquired. However, it would be possible for actual oil prices to deviate from purcliaser expectations, creating the potential for a broader range of oil deliveries for the SPR, from $61 \mathrm{MMB}$ to $171 \mathrm{MMB}$.

- Elk Hills Leasing

The study considered the effects of offering Elk Hills to the private sector under a leasing approach, whereby an initiāl bonus of $\$ 1.1$ billion would be paid to the Federal Government and lessees would bid a percentage royalty payment. A range of royalty percentages of 28 percent to 54 percent was derived. Were the funds to be earmarked for SPR fill, they would provide for an estimated 144 to $200 \mathrm{MMB}$ in SPR fill by the year 2000, if actual oil prices tracked with those projected by the lessees. A broader range of 126 to $218 \mathrm{MMB}$ is associated with cases in which the actual oil prices diverged substantially for prices projected at the time of original bidding. 
In sum, there are a variety of approaches for using Elk Hills to generate cash for fill of the SPR. None of the approaiches could permit a sustained fill rate of $75 \mathrm{MBD}$ until an inventory level of $1,000 \mathrm{MMB}$ was achieved. Of the three methods analyzed, under Base Case prices a revolving fund would yield the highest total SPR fill through the year 2000, full divestiture would yield the least, and leasing would provide an intermediate level. However, a broader range of outcomes could occur with divestiture or leasing because of the possibility of divergence between actual future oil prices and the expectations of the private sector at the time the divestiture or lease arrangements were undertaken.

\section{E. FEES}

The budget effects of expanding the SPR could be offset by increasing Federal revenues in a variety of ways, including fees levied on oil imports, on total oil consumption, or on consumption of a major product such as gasoline. Each of these approaches transfers the costs of the SPR from general taxpayers to oil users, to be reflected in the price of oil.

The fee levels required to offset SPR expenditures would depend on the rate of SPR fill, the level of oil prices, and the base on which the fees were levied. Table V presents a summary of the fee levels that would be associated with the Reference Case (75 MBD SPR fill and Base Case oil prices) assuming no exceptions are made (other than for Canadian imports) or refunds paid.

\section{Table V}

SPR Fee Levels for Selected Years (nominal dollars per unit)

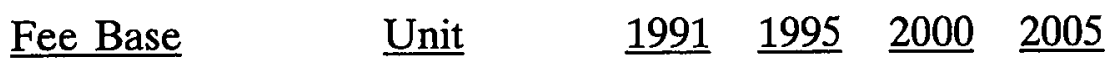

Imports

$\begin{array}{llrrrr}\text { Crude Only } & \text { BBL } & \$ .24 & \$ .41 & \$ .39 & \$ .37 \\ \text { Crude and Product } & \text { BBL } & .18 & .32 & .32 & .31\end{array}$

Domestic Crude plus

Imported Crude and

Product

BBL

$\begin{array}{llll}.10 & .20 \quad .20 \quad .21\end{array}$

Gasoline Consumption Gallon $\quad \begin{array}{lllll}0 & .005 & .010 & .010 & .011\end{array}$

The fee levels shown would cover not only SPR oil acquisition outlays but also costs for future acquisition and development of storage facilities. The schedules assume attaining a one billion barrcl SPR at a minimum fill rate of $75 \mathrm{MBD}$. Fees could be adjusted to 
cover only oil costs, and fees could be combined with other financing methods such as leasing.

With the exception of the fee on gasoline, provision could be made for rebating some or all of the revenues collected, at the time of an emergency drawdown of the SPR. However, any such rebate approaches would need to be carefully designed to avoid interference with the SPR sales process.

If oil prices were higher than in the Base Case, the SPR budget requirements would be higher, but it is expected that the consumption and import levels would be lower. Therefore, the absolute value of the fee per unit would need to rise. Conversely, lower oil prices would reduce SPR costs, but increase the fee base, permitting lower fee levels.

The fees would tend to increase the price of oil to the consumer, and there would likely be some "feedback" tendencies whereby higher fees induced lower consumption and lower imports. Such feedback effects have not been incorporated into the above estimates.

A preliminary analysis was undertaken of the effects of such fees on economic output levels. The conclusions were that (1) the broader the base for applying the fee, the lower its effect on Gross National Product (GNP); and (2) the effects on GNP, while small relative to the total size of the economy, could be large in relation to the new revenues raised in this manner. These GNP effects, along with the deductibility of such fees in calculating corporate income tax liabilities, would have indirect adverse effects on Federal tax revenues, which would partially offset the direct deficit-reduction effects of the fees. 


\section{F. INDUSTRIAL PETROLEUM RESERVE}

The Federal Government could transfer some or all responsibility for future increments of the SPR to the private sector by requiring petroleum industry participants to establish and maintain strategic oil stocks above the normal levels of inventory. This approach would reduce the direct budget costs for expanding the SPR, internalize the cost of strategic protection into prices, and place part of the strategic stockpile in private ownership.

The Industrial Petroleum Reserve (IPR) approach rests on two major premises: (1) that oil industry members and consumers, instead of all taxpayers, should pay for strategic petroleum inventories; and (2) that it is the availability of oil stocks in the U.S. during a disruption that is important not who owns them.

Nearly all U.S. partners in the International Energy Agency use compulsory private storage to achieve some or all strategic oil stockpiling objectives, and the SPR authorizing legislation, the Energy Policy and Conservation Act, provides for an IPR as part of the SPR.

In assessing any form of mandatory storage, three related points must be borne in mind. First, all else being equal, a mandatory approach is necessarily more costly than direct purchasc. Regulation may obscure the true costs of a program, but these costs exist nonetheless and can be very substantial. Second, while the insurance-based approach discussed below offers potential efficiency gains in several areas, these gains arise not from introducing new regulations but rather from introducing more market forces into the stockpiling process. Any SPR design would benefit by the introduction of more market forces. The current SPR design, for example, may contain its own inefficiencies, and one goal of policy should be to reduce them. Third, while a mandatory approach may be thought of as a way to concentrate the costs of the SPR on its more immediate beneficiaries, the same thing could be accomplished through the appropriate choice of user fees, as discussed above. Moreover, general Treasury financing necessarily involves a lower overall cost to society than mandatory storage.

The report presents one option, based on the idea of insurance, that could potentially offer efficiency gains relative to the current SPR design. These gains arise from introducing more market forces into the stockpiling process, rather than from the regulatory approach as such. It must be emphasized that any such efficiency gains could also be realized with the current SPR design.

Existing IPR approaches, however, such as those requiring firms to hold physical stocks of crude oil and products, suffer from a variety of disadvantages: they impose uneven (and sometimes large) costs on different firms, they are difficult to monitor, they may involve higher-cost storage methods, and they can increase administrative burdens. A new 
option presented in the study, based on the idea of insurance, would lighten the administrative burden, and perhaps reduce the overall cost to the economy. Under a certified access IPR, oil importers and refiners would be required to hold not physical stocks of oil, but rather claims entitling them to certain quantities of crude oil during a disruption. The oil might be owned by third parties such as domestic oil companies, other companies, or foreign governments. Government inspectors would check periodically to make sure that physical stocks backed each barrel claimed. Claims on oil could be traded among firms.

During a disruption, these claims could be redeemed for oil, just as a fire insurance policy pays the policyholder in the event of a fire. The oil could then be sold on the open market, or used directly by the importer or refiner who held the claim.

\section{G. STORAGE FACILITIES LEASING}

The SPR could lease storage facilities in conjunction with a decision to expand the Reserve beyond $750 \mathrm{MMB}$. The study outlines some of the special considerations involved in devising an SPR facilities lease, based on information obtained from discussions in late 1989 with potential lessors as well as experience gained from a 1978-79 DOE experience in attempting to procure facilities on a "turnkey" basis. The conclusions of this part of the study can be summarized as follows:

- A lease for permanent storage facilities would probably require that most or all of the lessor's investment be returned over the course of the guaranteed minimum term. This is because there currently is not a significant private market for such special-purpose facilities.

- In comparison to the purchase method, the lease method could stretch out SPR facilities outlays, as capital costs were amortized over a longer period. However, there effectively would be a transfer of interest costs from the Treasury to the DOE, and the DOE would be required to obligate funds for the entife minimum term of the lease. It is estimated that the near-term SPR BA effects for a lease could be as much as three times as high as the BA effects for direct DOE development, even if, using the standards in OMB Circular A-104, the present value costs for a lease were lower than the costs for direct development.

- Notwithstanding these BA effects, leasing could be economically attractive if it provided the Government with access to storage arrangements that could not be obtained 
through direct acquisition. For example, collocation of strategic and commercial storage could create the potential for economies to scale or support attractive oil acquisition opportunities. 
DEPARTMENT OF ENERGY

WASHINGTON, D.C. 20585

OFFICIAL BUSINESS

PENALTY FOR PRIVATE USE, $\$ 300$

$$
\text { FE-4.31 }
$$

